\title{
Molecular study of Astyanax altiparanae (Osteichthyes, Characidae) as a probable species complex
}

\author{
I.C. Deprá ${ }^{2,3}$, V.N. Gomes ${ }^{2,4}$, G.C. Deprá ${ }^{2,3}$, I.J. Oliveira ${ }^{2,5}$, \\ S.M.A.P. Prioli ${ }^{1,2}$ and A.J. Prioli ${ }^{2}$ \\ ${ }^{1}$ Departamento de Biotecnologia, Genética e Biologia Celular, \\ Universidade Estadual de Maringá, Maringá, PR, Brasil \\ ${ }^{2}$ Núcleo de Pesquisas em Limnologia Ictiologia e Aquicultura, \\ Universidade Estadual de Maringá, Maringá, PR, Brasil \\ ${ }^{3}$ Programa de Pós-Graduação em Biologia Comparada, \\ Universidade Estadual de Maringá, Maringá, PR, Brasil \\ ${ }^{4}$ Programa de Pós-Graduação em Ecologia de Ambientes Aquáticos Continentais, \\ Universidade Estadual de Maringá, Maringá, PR, Brasil \\ ${ }^{5}$ Curso de Graduação em Ciências Biológicas, \\ Universidade Estadual de Maringá, Maringá, PR, Brasil \\ Corresponding author: A.J. Prioli \\ E-mail: ajprioli@nupelia.uem.br
}

Genet. Mol. Res. 13 (3): 6015-6026 (2014)

Received July 1, 2014

Accepted July 15, 2014

Published August 7, 2014

DOI http://dx.doi.org/10.4238/2014.August.7.16

\begin{abstract}
Astyanax altiparanae, belonging to the bimaculatus group, which includes species with similar colors and morphology, occurs in the upper Paraná River basin. As the use of mitochondrial DNA has made great strides in the diagnosis of species, in previous researches, two strains were detected in A. altiparanae with a high divergence in the D-loop region, provisionally called AltoPR and AltoPR-D. Evidence led to the hypothesis that the two strains did not belong to the same species. Phylogenetic hypotheses were produced by maximum-likelihood. Mean internal distances of the AltoPR and
\end{abstract}


AltoPR-D groups were respectively 0.002 and 0.003 , with the distance between them being 0.037. Sequences from GenBank of specimens collected from the Paraíba do Sul River basin were also divided into two groups, of which one may be identified as AltoPR. Since the other group provided an intermediate distance when compared to AltoPR-D, an in-depth investigation was required. The other species analyzed showed a greater distance and was revealed to be a monophyletic taxon. The results suggested that they are really two species and that neither corresponds to the other species used in the current study.

Key words: DNA barcodes; D-loop; Species discrimination

\section{INTRODUCTION}

Astyanax altiparanae Garutti and Britski 2000, popularly known in Brazil as 'yellowtail lambari,' is distributed throughout the upper Paraná River basin and is one of the most abundant fishes in the river's floodplain (Agostinho et al., 2007). The species belongs to the bimaculatus group, a species complex with the same color pattern as Astyanax bimaculatus, or rather, a black oval strip stretching horizontally and two brown vertical bars in the humeral region, with a black spot on the caudal peduncle that extends to the extremities of the median caudal rays (Garutti and Britski, 2000).

It was previously thought that $A$. bimaculatus occurred extensively throughout South America, with type locality in Surinam. However, two revisions by Garutti $(1995,1998)$ limited the denomination to specimens in the northern area and excluded it from the basins of São Francisco, Paraná, lower Paraná-Paraguay, Uruguay, Ribeira de Iguape, and Paraíba do Sul Rivers and the Laguna dos Patos system. The Catalog of Fishes (Eschmeyer et al., 2014) reports that several valid species have already been described as subspecies of $A$. bimaculatus or considered to be synonymous. The above fact already reveals the problematic factor in the group.

In the wake of the recent development of species molecular diagnosis with investigations of mitochondrial sequences of the D-loop control region of Astyanax altiparanae, Soria (2004), Pie et al. (2009) and Prioli et al. (2012) discovered two haplogroups, which diverged at several sites, each having a 32-bp segment. According to Prioli et al. (2012), molecular differentiation may be compared to species of other genera. In addition, $5.1 \%$ of the nucleotides are diagnosed as haplogroup AltoPR and AltoPR-D (D is for deletion or lack of insertion) in the stretch of the D-loop region whose sequence was obtained. The homologue sequences of Pseudoplatystoma corruscans and $P$. fasciatum, which do not generate hybrids naturally (Bignotto et al., 2009), and Cichla kelberi and C. piquiti (Oliveira et al., 2006) provide 5.3 and $10 \%$ of the usable nucleotides for diagnosis, respectively.

The above evidence raises the hypothesis that a second species exists, which may be identified as A. altiparanae. If the hypothesis is correct, the species may be either a new species or an already described one, due to the morphological overlap in the bimaculatus group. Moreover, Soria (2004) and Prioli et al. (2012) provided D-loop sequences of Astyanax asuncionensis Géry 1972, a species from the basin of the Paraguay and lower Paraná Rivers. A asuncionensis also belongs to the bimaculatus group, but on the basis of an uncertain diagnosis when compared with $A$. altiparanae. Two highly dissimilar haplogroups occurred, 
both with a 32-bp deletion. According to these authors, the results seemed to show that the two strains of $A$. asuncionensis and the two strains of $A$. altiparanae should be upgraded to the species status.

No reports of other species of the bimaculatus group are extant for the upper Paraná River basin (Oliveira, 2011; Marreta, 2011). Marreta (2011) reconstructed the phylogeny of the species of the genus in the State of São Paulo, Brazil, and reported that Astyanax altiparanae was different from the others by approximately $14.15 \mathrm{Ma}$, according to estimates for base substitutions by Bermingham et al. (1997).

Besides A. asuncionensis, A. abramis (Jenyns 1842) and A. paraguayensis (Fowler 1918) are also in the basin of the Paraguay and lower Paraná Rivers, species of the bimaculatus group in the sense given by Garutti and Britski (2000). These authors report that the species have a striped pattern of chromatophores, visible in adults, and that they are shorter than A. altiparanae. Similar to A. asuncionensis, the specimens of A. lacustris of the São Francisco River basin show similarities with $A$. altiparanae, with some overlapping morphological characteristics. The presence of the species in the upper Paraná River is not unexpected since several species share the two basins. It is likely that this species corresponds to one of the strains discussed in the current research

Another fact that questions the taxonomic delimitation of $A$. altiparanae is that, in a recent publication (Pereira et al., 2011), the identification of the species Astyanax contrasted with the gene sequence analyses of cytochrome c oxidase (COI). Specimens collected in the Paraíba do Sul River and identified as A. bimaculatus had COI gene sequences that were more similar to those of specimens identified as A. altiparanae collected in the same samples compared to other specimens initially thought to be of the same species. Carvalho et al. (2011) also identified a species as $A$. bimaculatus. They did not find any divergence between COI sequences of specimens of this species and A. lacustris (considered a subspecies of $\mathrm{A}$. bimaculatus). The above reinforces the doubt with regard to the diagnosis of the species that are closer to the bimaculatus group.

Data available at the Bold Systems platform reveal specimens identified as A. altiparanae with COI sequences which are highly close to sequences of specimens identified as $A$. asuncionensis, A. bimaculatus, A. lacustris and others (BoldSystems, accessed on July 21, 2014). Pereira et al. (2011) also presented difficulties in COI sequences for the delimitation of the species Astyanax. According to Garutti and Britski (2000), the species A. bimaculatus, sensu Linnaeus, is restricted to specimens with one tooth in the jaw and that are not extant in the Paraíba do Sul River basin. On the other hand, since mistakes in the diagnosis of some of these specimens have occurred, it may be supposed that the two species correspond to the AltoPR and AltoPR-D groups, which may be easily tested by comparing D-loop and COI sequences.

As reported by Hebert et al. (2003), the current literature shows a high rate of examples of nucleotide divergences, especially in COI, for comparison. Hubert et al. (2008) were one of the first to study the differentiation of this gene in freshwater fish in their analysis of the ichthyofauna of Canada, very similar to what Carvalho et al. (2011) and Pereira et al. (2011) did in the basins of the São Francisco and Rio Paraíba do Sul Rivers. Genetic, intraspecific and intrageneric distances in all the above-mentioned studies varied widely.

On the basis of a wide variety of sequences of the cytb gene, Johns and Avise (1998) estimated that approximately $98 \%$ of pairs of co-generic fish species feature more than $2 \%$ 
distances and approximately 10\% have a distance between 4 and 5\%. Genetic distance based on mitochondrial genes may be an asset in the discrimination of possible cryptic species.

Since genetic distance may have resulted only from population structure, Hebert et al. (2004) undertook a study of the range of the ratio between interspecific and intraspecific distance in bird species of North America. They found that the ratio was higher than or equal to 10 in approximately $90 \%$ of the species, even though they warned that recent speciations or hybridizations may provide even lower rates.

Mallet et al. (2005) report that theoretically the intraspecific genetic distances in species of the neotropical region may approach the interspecific ones since the population sizes of neotropical species probably remained more constant, while northern species underwent mass extinctions during the glacial periods. The latter events must have contributed towards a greater interspecific distance by the chance elimination of sister species of survivors and a lower intraspecific diversity caused by population issues.

Gomes (2011) reported that presumed valid pairs of species in the upper Paraná River basin, showed intraspecific distances closer to interspecies ones in five genera. Maybe a similar result is highly probable in the current issue.

The present study evaluated the taxonomic status of the AltoPR and AltoPR-D groups, normally considered to belong to the species $A$. altiparanae, on the basis of mitochondrial sequences between them and between them and other species of the genus Astyanax, to determine whether they should be considered as two different species and, if so, whether they correspond to already described species or to a new species.

\section{MATERIAL AND METHODS}

\section{Fish sampling}

Specimens of A. altiparanae collected at sites in the upper Paraná River basin are shown in Figure 1. Specimens were preserved by injecting commercial alcohol into their abdominal cavities and submerging in alcohol, and they were then deposited in the Ichthyologic Collection of Nupélia, Universidade Estadual de Maringá, Maringá, PR, Brazil.

Twelve specimens (AstyPR-01 - AstyPR-12) from the floodplain of the upper Paraná River basin were analyzed. Three specimens from Rio do Campo (AstyPR-13 - AstyPR-15) and four specimens from Córrego Soares (AstyPR-16 - AstyPR-19) were also analyzed. Sequences deposited in GenBank and in BoldSystems were also included for analysis.

\section{PCR and sequencing}

DNA was extracted by the phenol and chloroform method, according to Oliveira et al. (2002) and Antunes et al. (2010). Amplifications were performed with Platinum Taq DNA polymerase (Invitrogen, Carlsbad, CA, USA) in a MJ Research PTC-100 thermocycler. Primers L15774M (5'-CAACATGAATTGGAGGTATACCAGT-3') and H16498 (5'-CCTGAAGTAGGAACCAGATG-3') were used for the D-loop region, according to Prioli et al. (2002). PCR was carried out according to Oliveira et al. (2006) and PanarariAntunes et al. (2012). The COI gene (cytochrome oxidase c subunit 1) was partially amplified with primers H7152 (5'-CACCTCAGGGTGTCCGAARAAYCARAA-3') and L6448-F1 
(5'-TCAACCAACCACAAAGACATTCGGCAC-3'), and the protocol was 2 min at $94^{\circ} \mathrm{C}$, 35 cycles of $30 \mathrm{~s}$ at $94^{\circ} \mathrm{C}, 40 \mathrm{~s}$ at $52^{\circ} \mathrm{C}$, and $1 \mathrm{~min} 30 \mathrm{~s}$ at $72^{\circ} \mathrm{C}$, and $10 \mathrm{~min}$ at $72^{\circ} \mathrm{C}$. DNA sequences were obtained with MegaBACE (Amersham Biosciences, Piscataway, NJ, USA).
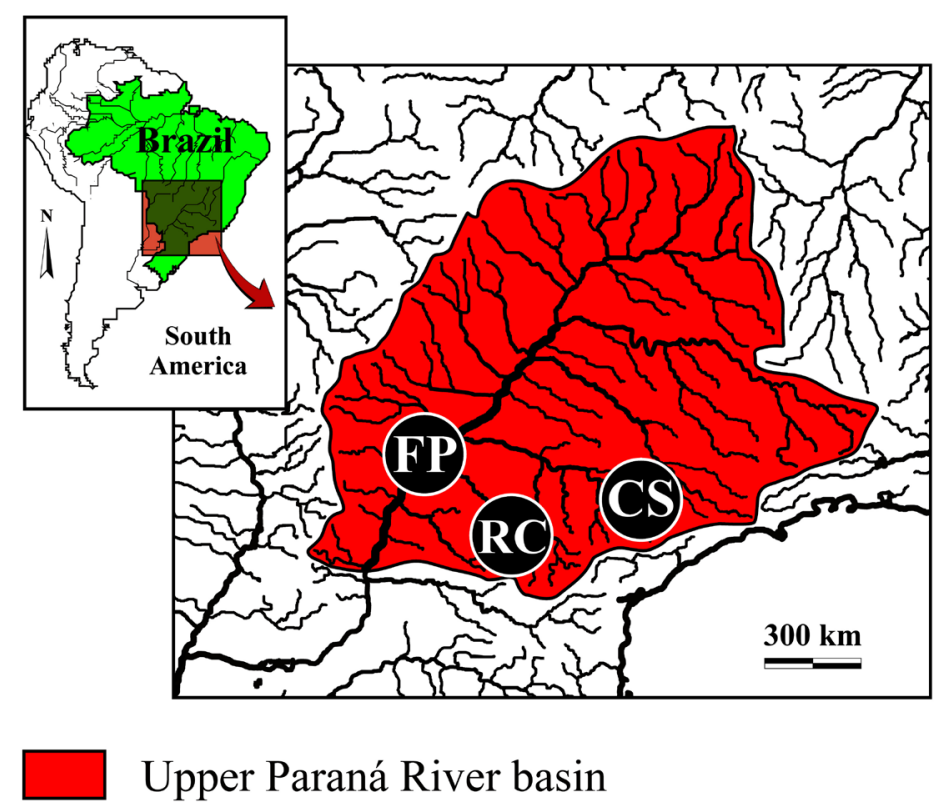

Figure 1. Sampling locations in which Astyanax altiparanae populations were surveyed. $\mathrm{FP}=$ floodplain of the

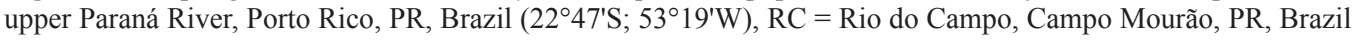
$\left(23^{\circ} 59^{\prime} \mathrm{S} ; 52^{\circ} 20^{\prime} \mathrm{W}\right)$, and CS = Córrego Soares, tributary of the Itapetininga River, São Miguel Arcanjo, SP, Brazil $\left(23^{\circ} 46^{\prime} \mathrm{S} ; 47^{\circ} 43^{\prime} \mathrm{W}\right)$.

\section{Analyses}

Sequences were edited and aligned to the D-loop and COI nucleotide sequences available at GenBank with MEGA 6.0 (Tamura et al., 2013). The evolution model for each mitochondrial region was determined by Bayesian Information Criterion (BIC) and corrected Akaike Information Criterion (AICc). Phylogenetic hypotheses were obtained by maximumlikelihood for the D-loop region and by neighbor-joining for COI sequences with MEGA 6.0.

\section{RESULTS}

Eighteen sequences of the D-loop region with a minimum of 448 bases were obtained and 66 variable nucleotides were reported among the specimens (Table 1). Sequences revealed the two haplogroups already reported by Prioli et al. (2012), with an insertion or deletion events of $35 \mathrm{bp}$. Although Prioli et al. (2012) reported a 32-bp indel, the difference seems to have been caused by a variation in sequence alignment. The specimen AstyPR-04 was reported with a 35-bp segment but with a nucleotide polymorphism compatible to that of haplogroup AltoPR-D, which does not feature the 35-bp segment. 
Table1. Polymorphic nucleotide sites of mitochondrial D-loop sequences.

\begin{tabular}{|c|c|c|}
\hline \multirow[t]{2}{*}{ Haplogroup } & \multirow[t]{2}{*}{ Specimen } & Nucleotide \\
\hline & & 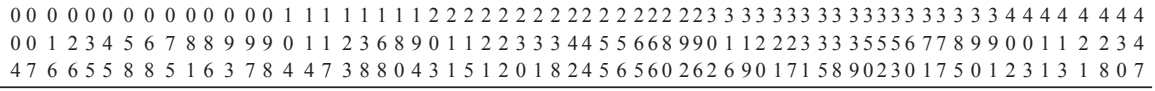 \\
\hline & & 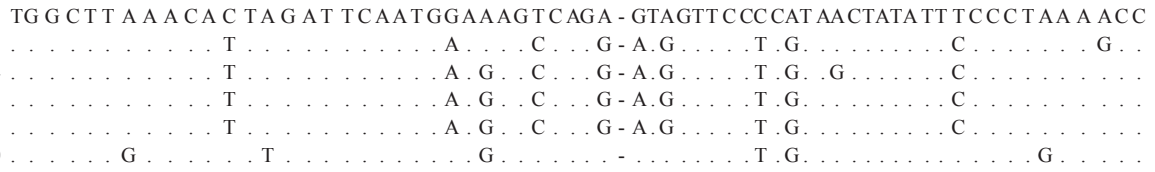 \\
\hline PR-D & $\begin{array}{l}\text { AstyPR-02 } \\
\text { AstyPR-03 } \\
\text { AstyPR-04 } \\
\text { AstyPR-05 } \\
\text { AstyPR-06 } \\
\text { AstyPR-07 } \\
\text { AstyPR-09 } \\
\text { AstyPR-11 } \\
\text { AstyPR-12 } \\
\text { AstyPR-17 } \\
\text { AstyPR-18 } \\
\text { AstyPR-19 }\end{array}$ & 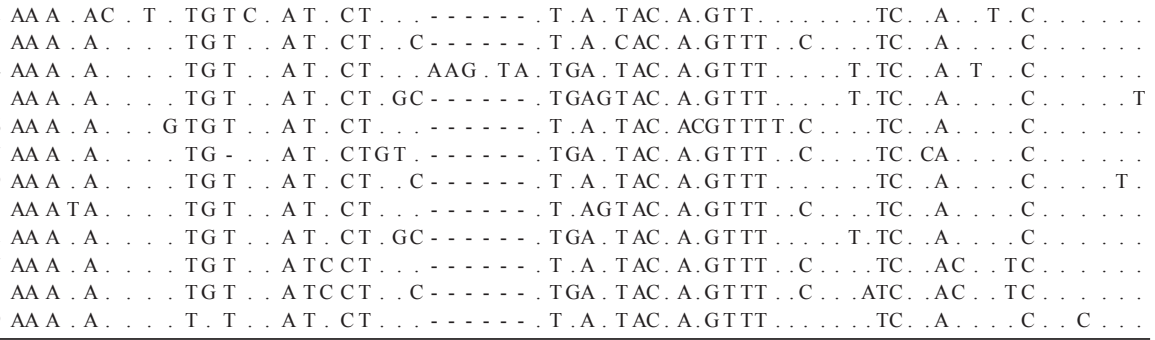 \\
\hline
\end{tabular}

Table2. Polymorphic nucleotide sites of mitochondrial COI sequences.

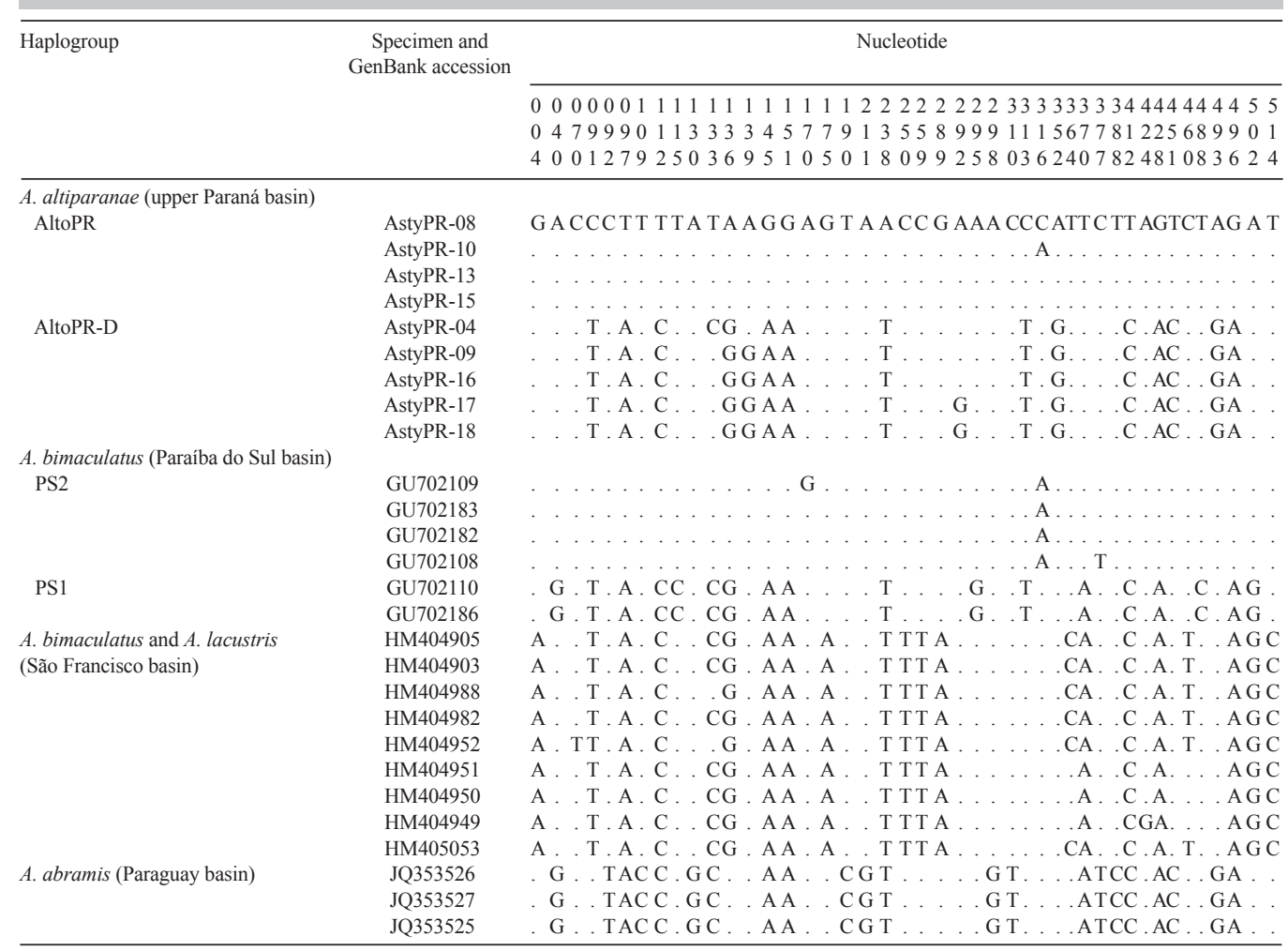


Nine COI sequences of $A$. altiparanae were reported with $532 \mathrm{bp}$ and with an already determined D-loop nucleotide polymorphism. Four COI sequences were obtained from specimens without the 35-bp block in the D-loop and four sequences with a 35-bp block. COI sequence of the specimen AstyPR-04 with a 35-bp block was also obtained, albeit with a nucleotide pattern without the block. Excluding the indel block, eighteen polymorphic sites were found corresponding to 0.037 of the total nucleotide sites (Table 2).

Specimens collected from the São Francisco River basin by Carvalho et al. (2011) were identified as A. bimaculatus and Astyanax lacustris, whereas specimens from the Paraíba do Sul River basin collected by Pereira et al. (2011) were identified as A. bimaculatus. They were included in the COI sequence analyses available at GenBank and BoldSystems. Specimens from the upper Paraná River basin, such as Astyanax abramis, were also included, but no other sequences of other species of the bimaculatus group were included. BoldSystems shows only graphs with $A$. asuncionensis practically similar to A. bimaculatus and A. altiparanae, but no COI sequences are available. The other species described in the genus and registered for other basins are unequivocally diagnosable.

Kimura 2-parameter with distribution $\Gamma$ (parameter 0.50) was the model chosen with $\mathrm{AICc}$ and BIC for the D-loop region. Mean distances between specimens of each strain were $1.2 \%$ for AltoPR and $1.8 \%$ for AltoPR-D, and $7.5 \%$ between the two. The phylogenetic reconstructions were compatible with the deletion/insertion-based separation, excepting AstyPR-04, as previously mentioned (Figures 2 and 3). However, genetic distance between the latter and the specimens of each group implies that a recent insertion in the ancestral strain of this specimen must have occurred. In fact, the insertion is part of a series of three adjacent repetitions, only one of which is a substitution (Figure 2). Repetitions occurred in all specimens, typically two in the AltoPR-D group and three in AltoPR group. Moreover, repeated sequences in specimens of the AltoPR group generally had more substitutions.

\section{5' GTACATAATATGTATAATTATACATATATGTACTA GTACATAATATGTATAATTATACATATATGTACTA GTACATAATATGTATAATTGTACATATATGTACTA 3'}

Figure 2. Segment of D-loop sequence of the specimen AstyPR-04 (bases 126 to 230), showing that the indel in the region is a tandem repetition.

Kimura 2-parameter model with gamma distribution (parameter 0.12) was selected for $\mathrm{COI}$ sequence. In the case of distances between specimens grouped by locality, all populations were cohesive, with the exception of specimens in the Paraíba do Sul River basin. The latter were divided into two groups according to the proximity between specimens. Groups of the basins of the Paraíba do Sul and São Francisco Rivers were classified as PS (divided into PS1 and PS2) and SF, respectively. Mean internal distances of the AltoPR and AltoPR-D groups were 0.2 and $0.3 \%$, respectively, and $3.7 \%$ between them. 


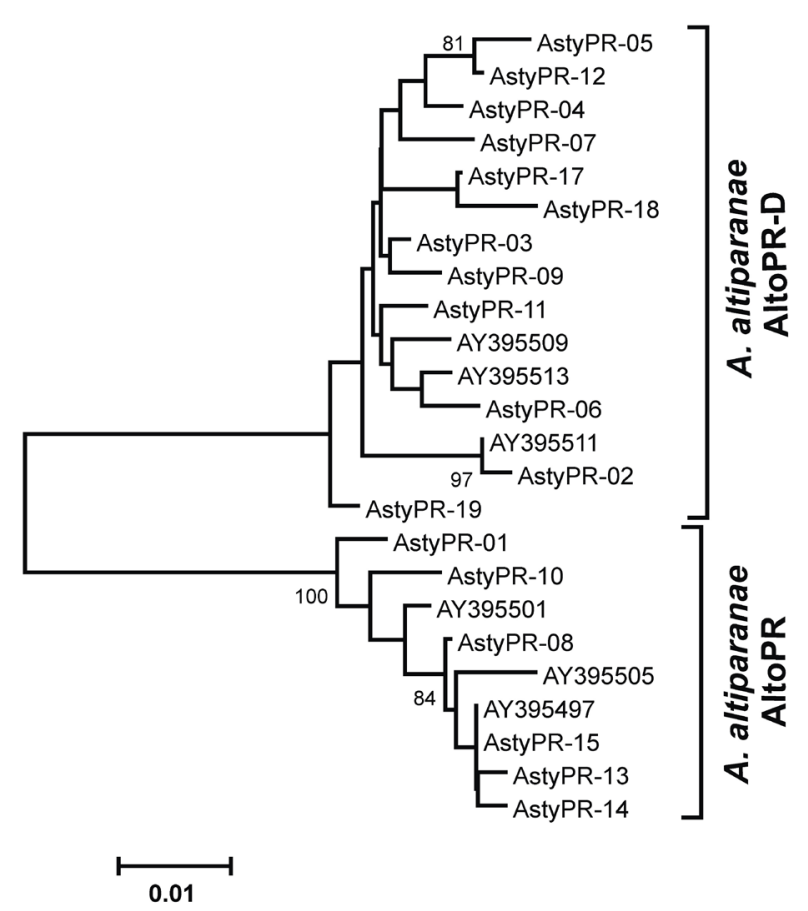

Figure 3. Maximum likelihood tree built by Kimura 2-parameter model, with distribution $\Gamma$ (parameter 0.50 ), on the basis of D-loop region of Astyanax altiparanae and 1000 bootstrap resamplings.

Table 3 shows the genetic distances based on the COI gene, including groups formed by the sequences of GenBank and BoldSystems, demonstrating correspondence between AltoPR and the so-called PS1 group. Groups AltoPR-D and PS2 showed a relatively large distance. Figure 4 demonstrates the result of COI-based phylogenetic analysis, with all the groups forming strongly supported monophyletic clades.

Table 3. Genetic distances within and between haplogroups of three species of Astyanax, calculated using COI gene and the evolution model Kimura 2-parameter, with distribution $\Gamma$ (parameter 0.12).

\begin{tabular}{lllllll}
\hline & \multicolumn{2}{c}{ A. altiparanae } & & & A. bimaculatus & A. abramis \\
\cline { 2 - 3 } & AltoPR & AltoPR-D & & PS1 & PS2 & SF \\
\hline A. altiparanae AltoPR & 0.002 & & & & & \\
A. altiparanae AltoPR-D & 0.037 & 0.003 & & & \\
A. bimaculatus PS1 & 0.001 & 0.040 & & 0.001 & & \\
A. bimaculatus PS2 & 0.050 & 0.026 & & 0.053 & 0.000 & \\
A. bimaculatus SF & 0.054 & 0.037 & & 0.058 & 0.033 & 0.003 \\
A. abramis & 0.076 & 0.079 & 0.057 & 0.085 \\
\hline
\end{tabular}

PS1 and PS2 = haplogroups of $A$. bimaculatus of Paraíba do Sul River. SF = A. bimaculatus of São Francisco River. Sequences of PS1, PS2, SF, and A. abramis were obtained from GenBank. 


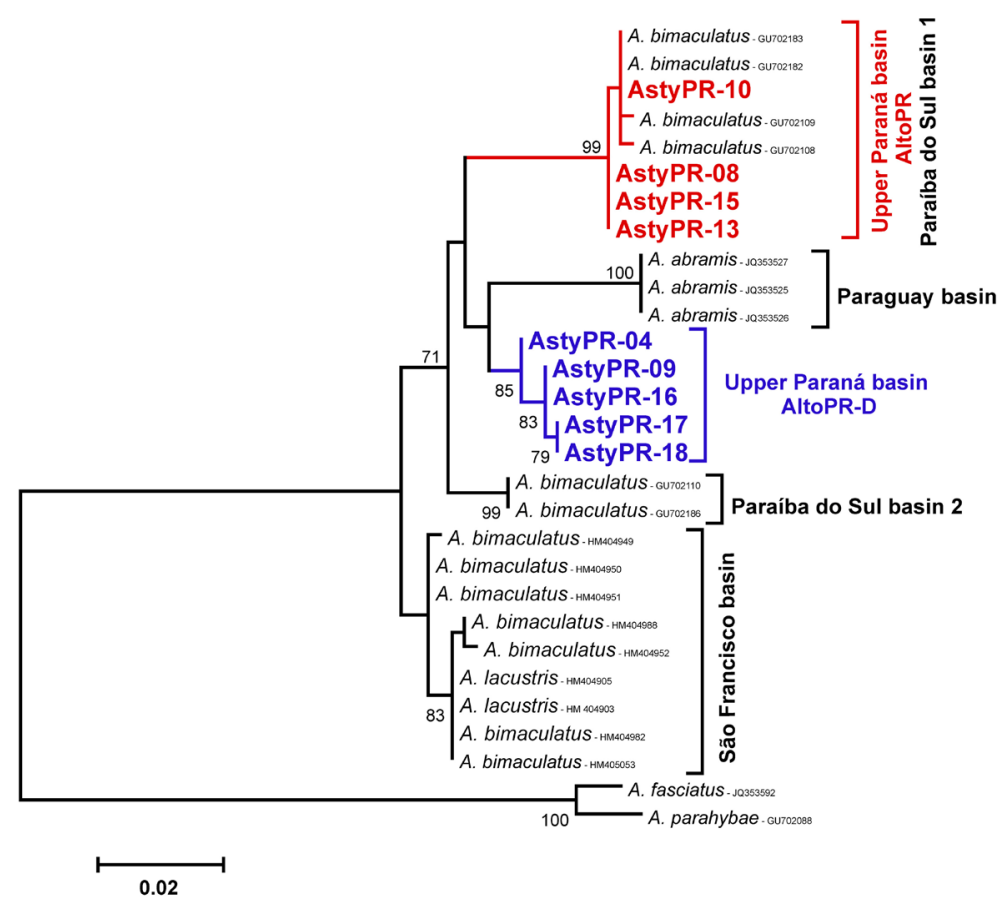

Figure 4. Maximum likelihood tree built by Kimura 2-parameter model, with distribution $\Gamma$ (parameter 0.12 ), on the basis of COI gene of $A$. altiparanae and 1000 bootstrap resamplings.

\section{DISCUSSION}

The D-loop region sequence of the specimen AstyPR-04, collected from the floodplain of the upper Paraná River basin, with 35 bp more than the others from the AltoPR-D group, revealed that the indel phenomenon is not a determinant for the division between the groups. The findings that the fragment, lacking in most specimens of this group, has only a slight variation in the adjacent stretch and that a tandem repetition occurs in AstyPR-04 with no base substitutions, suggest that some mechanism produces the sequence duplication sporadically.

COI gene sequences obtained within and between the strains AltoPR and AltoPR-D confirm that the distance between the two is more than 10 times greater than the mean distance between the specimens of each. Since the ratio is close to that reported by Hebert et al. (2004) in birds, there is strong evidence in favor of the hypothesis that they are two distinct species. In the case of the D-loop region, the rule may not be applicable since the ratio of the distances between the strains and internal means is much less than 10 times. The genetic distance based on the COI gene was practically nil between the strain AltoPR and one of the groups of specimens of the Paraíba do Sul River basin, called PS1 (Table 3). This fact practically reveals that these specimens belong to the same species.

Contrastingly, the distance between the other specimens of the Paraíba do Sul River basin, called group PS2, and the group AltoPR-D, was relatively high. When only this distance is taken into account, another hypothesis may be proposed, or rather, that there may be a third species, under the name A. altiparanae, according to the research by Johns and Avise (1998) 
and Gomes (2011). Since the distance is only a few times higher than the mean distance in group AltoPR-D, such a conclusion may not be valid, according to Hebert et al. (2004).

The results indicated that the identifications of specimens supposedly A. bimaculatus, may have to be revised. According to Garutti and Britski (2000), A. bimaculatus does not occur in the São Francisco River basin, and therefore, only the occurrence of A. lacustris may be suggested for this river basin.

The species included in this investigation are genetically close and the phylogenetic hypotheses obtained are not so strongly supported with regard to the location of the species within the genus. The above suggests that the dispersion of the ancestral species and the isolation of the river basins could have occurred within a short and relatively recent interval of time. This event is similar to that described by Mallet et al. (2005) who reported that there is a small hiatus between intraspecific diversity and interspecific distance when compared with that reported by Carvalho et al. (2011) and Pereira et al. (2011) for the Paraíba do Sul and São Francisco River basins, respectively. However, the current analysis included only a small clade of the genus Astyanax, and may not represent the whole genus.

Although the phylogenetic relationships between the specimens of different groups are not sufficiently clear, the results showed that they are monophyletic groups and that the $A$. lacustris and A. abramis specimens correspond neither to AltoPR nor to AltoPR-D. Therefore, the results reinforce the idea that a new species has been discovered and should be described, dividing the taxon currently defined as A. altiparanae. The bimaculatus group includes other species, and even if these species are still clearly distinct by classical taxonomy, as in the case of Astyanax paraguayensis, they should be included in further analyses to be undertaken.

Through its heredity mechanism, mitochondrial DNA may provide contradictory phylogenetic relationships as a consequence of such phenomena as introgression. Consequently, a study that examines nuclear sequences as well will be highly informative. Similarly, cytogenetic data such as those by Fernandes and Martins-Santos (2004) may complement the current investigation. These authors detected differences on the chromosome scale between specimens collected in the Ivaí River basin and those in the Porto Rico area. It is very interesting that these differences have been found only in allopatry. This fact encourages studies that compare such data to the molecular data currently presented. Since species are ecological units and that such an aspect is fundamental for ecologists, a detailed study of the distribution and behavior of the two strains should be performed.

Another fact in the current study deals with the lack of specimens of the AltoPR group in the samples of Córrego Soares (SP) and of AltoPR-D in the samples of Rio do Campo, an affluent of the Paraná River. The amount of genotyped specimens in the two cases does not qualify that the sample of the two populations is representative. However, it is the first time that the possibility of a spatial separation of the groups is suggested.

Finally, one has to take into account that cases of morphologically indistinct species have only recently been considered. Molecular distinction should not be equivalent to a description of the species. Deeper morphological studies are needed so that one of the A. altiparanae strains may be considered a valid species even though molecular taxonomy confirms it.

\section{ACKNOWLEDGMENTS}

Research supported by CNPq-PELD (site 6) and CAPES. The authors gratefully acknowledge C.S. Pavanelli for valuable discussions and suggestions, W.J. Graça for assisting 
with species identification, and Nupélia-UEM for logistic support.

\section{REFERENCES}

Agostinho AA, Pelicice FM, Petry AC, Gomes LC, et al. (2007). Fish diversity in the upper Paraná River basin: habitats, fisheries, management and conservation. Aquat. Ecosys. Health Manag. 10: 174-186.

Anonymous (2014). Barcode of Life Data Systems-BoldSystem. Available at (http://www.boldsystems.org)-(http://bins. boldsystems.org/index.php/Public_BarcodeCluster?clusteruri=BOLD:AAA7659)-(http://bins.boldsystems.org/ index.php/Public_BarcodeCluster?clusteruri=BOLD:ACK7589). Accessed July 21, 2014.

Antunes RSP, Gomes VN, Prioli SMAP, Prioli RA, et al. (2010). Molecular characterization and phylogenetic relationships among species of the genus Brycon (Characiformes: Characidae) from four hydrographic basins in Brazil. Genet. Mol. Res. 9: 674-684.

Bermingham E, McCafferty SS and Martin AP (1997). Fish Biogeography and Molecular Clocks: Perspectives from the Panamian Isthimus. In: Molecular Systematics of Fishes (Kocher T and Stepien CA, eds.). Academic Press, San Diego, 113-128.

Bignotto TS, Prioli AJ, Prioli SMAP, Maniglia TC, et al. (2009). Genetic divergence between Pseudoplatystoma corruscans and Pseudoplatystoma reticulatum (Siluriformes: Pimelodidae) in the Parana River Basin. Braz. J. Biol. 69: 681-689.

Carvalho DC, Oliveira DA, Pompeu PS, Leal CG, et al. (2011). Deep barcode divergence in Brazilian freshwater fishes: the case of the Sao Francisco River basin. Mitochondrial DNA 22 (Suppl 1): 80-86.

Eschmeyer WN (2014). Catalog of Fishes. California Academy of Sciences. [http://research.calacademy.org/research/ ichthyology/catalog/fishcatmain.asp]. Accessed on June 30, 2014.

Fernandes CA and Martins-Santos IC (2004). Cytogenetics study in two population of Astyanax altiparanae (Pisces, Characiformes). Hereditas 141: 328-332.

Garutti V (1995). Revisão taxonômica dos Astyanax (Pisces, Characidae) com Mancha Umeral Ovalada e Mancha no Pedúnculo Caudal, Estendendo-se à Extremidade dos Raios Caudais Medianos, das Bacias do Paraná, São Francisco e Amazônica. Livre-docência thesis, IBILCE-Unesp, São José do Rio Preto.

Garutti V (1998). Descrição de uma espécie nova de Astyanax (Teleostei, Characidae) da bacia do Tocantins, Brasil. Iheringia 85: 115-122.

Garutti V and Britski HA (2000). Descrição de uma espécie nova de Astyanax (Teleostei: Characidae) da bacia do alto Rio Paraná e considerações sobre as demais espécies do gênero na bacia. PUCRS Série Zool. 13: 65-88.

Gomes VN (2011). Avaliação da Sequência Nucleotídica do Gene Mitocondrial Citocromo Oxidase I na Identificação de Espécies de Peixes Neotropicais. Master's thesis, Universidade Estadual de Maringá, Maringá.

Hebert PDN, Ratnasingham S and deWaard JR (2003). Barcoding animal life: cytochrome c oxidase subunit 1 divergences among closely related species. Proc. Biol. Sci. 270 (Suppl 1): S96-S99.

Hebert PDN, Stoeckle MY, Zemlak TS and Francis CM (2004). Identification of birds through DNA Barcodes. PLoS Biol. 2: e312.

Hubert N, Hanner R, Holm E, Mandrak NE, et al. (2008). Identifying Canadian freshwater fishes through DNA barcodes. PLoS One 3: e2490.

Johns GC and Avise JC (1998). A comparative summary of genetic distances in the vertebrates from the mitochondrial cytochrome b gene. Mol. Biol. Evol. 15: 1481-1490.

Mallet J, Isaac NJB and Mace GM (2005). Response to Harris and Froufe, and Knapp et al.: Taxonomic inflation. Trends Ecol. Evol. 20: 8-9.

Marreta MA (2011). Evidências Moleculares dos Padrões Evolutivos e Filogeográficos de Populações de Astyanax paranae (Pisces: Characidae) com base em caracteres do DNA mitocondrial. Master's thesis, Instituto de Biociências, Unesp, Rio Claro.

Oliveira AV, Prioli AJ, Prioli SMAP, Pavanelli CS, et al. (2002). Diversity and genetic distance in populations of Steindachnerina in the upper Parana river floodplain of Brazil. Genetica 115: 259-267.

Oliveira AV, Prioli AJ, Prioli SMAP, Bignotto TS, et al. (2006). Genetic diversity of invasive and native Cichla (Pisces: Perciformes) populations in Brazil with evidence of interspecific hybridization. J. Fish Biol. 69: 260-277.

Oliveira CAM (2011). Estudo taxonômico de Astyanax Baird \& Girard, 1854 e Deuterodon Eigenmann, 1907 (Ostariophysi: Characiformes: Characidae) de três bacias hidrográficas do Estado do Paraná. Master's thesis, Universidade Estadual de Maringá, Maringá.

Panarari-Antunes RS, Prioli AJ, Prioli SMAP, Gomes VN, et al. (2012). Genetic divergence among invasive and native populations of Plagioscion squamosissimus (Perciformes, Sciaenidae) in Neotropical regions. J. Fish Biol. 80: 24342447. 
Pereira LH, Maia GM, Hanner R, Foresti F, et al. (2011). DNA barcodes discriminate freshwater fishes from the Paraiba do Sul River Basin, Sao Paulo, Brazil. Mitochondrial DNA 22 (Suppl 1): 71-79.

Pie MR, Baggio RA, Boeger WA, Patella LA, et al. (2009). Molecular data reveal a diverse Astyanax species complex in the upper Iguacu River. J. Fish Biol. 75: 2357-2362.

Prioli SMAP, Prioli AJ, Júlio Jr HF, Pavanelli CS, et al. (2002). Identification of Astyanax altiparanae (Teleostei, Characidae) in the Iguaçu River, Brazil, based on mitochondrial DNA and RAPD markers. Genet. Mol. Biol. 25: 421-430.

Prioli AJ, Carlo VA, Soria TV, Prioli SMAP, et al. (2012). Mitochondrial D-loop nucleotide diversity in Astyanax (Osteichthyes, Characidae) from the upper Parana and upper Paraguay River basins. Genet. Mol. Res. 11: 1064-1074.

Soria TV (2004). Diversidade em seqüências da região controle do DNA mitocondrial de populações de Astyanax da bacia do alto Rio Paraná. Master's thesis, Universidade Estadual de Maringá, Maringá.

Tamura K, Stecher G, Peterson D, Filipski A, et al. (2013). MEGA6: Molecular Evolutionary Genetics Analysis version 6.0. Mol. Biol. Evol. 30: 2725-2729. 